Marquette University

e-Publications@Marquette

College of Communication Faculty Research and

Publications

Communication, College of

$4-1-2003$

LBJ, the Rhetoric of Transcendence, and the Civil Rights Act of 1968

Steven R. Goldzwig

Marquette University, steven.goldzwig@marquette.edu

Published version. Rhetoric \& Public Affairs, Vol. 6, No. 1 (Spring 2003): 25-53. DOI. (C) 2003

Michigan State University Press. Used with permission. 


\title{
LBJ, the RHetoric OF Transcendence, AND the CIVIL RIGHTS Act OF 1968
}

\author{
SteVen R. GoldzWIG
}

The Civil Rights Act of 1968 was the result of a complex convergence of presidential public persuasion in a context of increasing domestic violence associated with a series of summer disturbances and the assassination of Martin Luther King, Jr. Analysis of Lyndon Johnson's public discourse supporting the 1968 Civil Rights Act reveals that rhetorical transcendence was employed as a recurrent strategy in attempts to pass legislation.

[T] he very base of man's condition is his home: he must find promise and peace there. -Lyndon Baines Johnson, "Special Message to Congress on Urban Problems: 'The Crisis of the Cities."'

We are all condemned to live together.

— attributed to Albert Camus

$\mathrm{T}$ he struggle for civil rights in America has perhaps become the key touchstone for acknowledging, monitoring, and continuing to pursue the realization of American democratic ideals and principles. Perhaps no modern U.S. era symbolizes a higher emphasis on the federal pursuit of civil rights than that represented by the triumphs of Lyndon Johnson's domestic policies in the mid and late 1960s. In particular, the Civil Rights Act of 1964 and the Voting Rights Act of 1965 have served as foci for analyses of both domestic presidential policy success and the realization of civil rights movement goals and objectives. Indeed, these two pieces of legislation have become indelible markers on the long, bloody road to equal rights for minorities, and they stand as significant normative criteria in our continuing discernment on the state of justice in America. The civil liberties enacted in and protected through these laws have reverberated in the hopes of earlier generations of Americans and continue to have significant repercussions today.

Steven R. Goldzwig is Professor of Communication Studies at Marquette University in Milwaukee, Wisconsin.

(C) Rhetoric \& Public Affairs

Vol. 6, No. 1, 2003, pp. 25-54

ISSN 1094-8392 
Less well known and less studied by historians, political scientists, and communication scholars alike was Lyndon Johnson's third major civil rights initiative, the Civil Rights Act of 1968, signed into law on April 11, 1968. During the Johnson years the new civil rights frontier was extended to the urban ghettoes of the north. This extension tested the federal government's capacities to respond effectively to an increasingly complex, interdependent set of social problems. Overpopulation, poverty, segregated housing, poor schools, and unemployment coalesced into a northern nightmare of intractable inner-city realities. Such dire social needs seemed to require a holistic and far-reaching public policy. The idea was to root out a history of human deprivation. Thus, in the Johnson administration civil rights were important foci for domestic policy, and poverty and education programs were often viewed as key instruments in achieving civil rights. Social justice required government to fashion laws and conduct policies that would protect human rights and vanquish poverty. The Johnson administration adopted this philosophy because participants sincerely believed in their ability to implement a revised formula reflecting an "enlightened" approach. This was the far-reaching rationale of "The Great Society." This slogan symbolized a quest that was both political and moral. ${ }^{2}$

One of the most persistent impediments to the full realization of The Great Society was the problem of housing. Since the close of World War II, access to adequate housing was particularly difficult for impoverished African Americans. Moreover, patterns of segregation in the postwar years almost guaranteed that housing would remain a persistent and intractable problem. When Congress passed the Housing Act of 1949, it proclaimed a simple goal: "A decent home and a suitable living environment for every American family." While laudable, this objective went largely unfulfilled. In fact, by 1963 the U.S. Commission on Civil Rights had determined that housing was perhaps the most ubiquitous, deeply rooted civil rights problem in the nation. As one member of Congress observed, "Suburban housing, virtually closed to non-whites, leads to Negro central cities, with consequent segregation in schools. Bold steps are needed to change this pattern. But how?"3

Part of the difficulty of answering this question can be demonstrated in Lyndon Johnson's struggle to combat housing discrimination in the United States. My case study concerns the 1968 Civil Rights Act. Relying, in part, on primary research drawn from the archives at the Lyndon B. Johnson Presidential Library, I will argue that one of the most difficult and intransigent civil rights issues faced by the president was that of open housing. I shall place my primary focus on the open housing provision of the 1968 Civil Rights Act and maintain that this provision might never have been realized as public policy in the United States without a number of converging circumstances that helped shape, constrain, and finally release this controversial provision from years of failed legislative activity. In particular, I shall argue that a complex convergence of presidential public persuasion, internal and external persuasive advice to Lyndon Johnson, increasing violence associated with civil 
unrest at home, domestic protest over the Vietnam War, and finally, the assassination of Martin Luther King, Jr. all conspired in time to make a once untenable public policy initiative a codified reality. Federal law would finally address housing discrimination in the United States. Furthermore, I will argue that the battle over the 1968 Civil Rights Act was emblematic of a recurrent Johnsonian rhetorical strategy, a strategy that earmarked needed legislation as an act of national transcendence. This particular strategy, it will be argued, was a hallmark of the president's persuasive activity.

To support the above claims I will (1) outline a brief history of attempts by the Johnson administration to address housing as a substantive public policy issue; (2) relate this history to the regnant rhetorical situation, including the various interest groups shaping and informing this complex public policy initiative; (3) detail two major "external" events that constrained LBJ's rhetoric and ultimately proved pivotal to the final realization of the act: the summer riots during the Johnson years and the assassination of Martin Luther King, Jr.; and (4) discuss the rhetorical and public policy implications of the discursive machinations evidenced in this study. Both spoken and unspoken words play a central role in the outcome of the 1968 Civil Rights Act, and I will be attentive to each.

\section{Housing: The New Frontier in Civil Rights Policy}

In February 1964, many Americans "feared school integration would mean housing integration and falling property values." 4 The administration fought valiantly to overturn such assumptions. Attorney General Nicholas Katzenbach addressed candidly fears surrounding calls for integrated housing, and he was equally adamant in attempts to allay such trepidations: "You know what these myths are-they are as much a part of American folklore as Paul Bunyan: 'If we let one in they will all come in.' 'They will take over. 'All the whites will move out.' The neighborhood will deteriorate. 'Property values will go down.' . . The only way to counter the mythology of racism is with facts and knowledge." ${ }^{5}$ Furthermore, Katzenbach argued that segregation was impractical, politically and economically unsound, and immoral. Those themes had also been developed by the moderate members of the civil rights movement. The administration's new emphasis on housing was based on statistics that evidenced an horrendous housing shortage. ${ }^{6} \mathrm{~A}$ most vexing question remained: How should the federal government proceed in its efforts to eliminate the pain associated with this reality?

The "how" question was reduced to a struggle over the most effective means. Johnson considered a difficult choice between executive action and renewed civil rights legislation. The president was under considerable pressure as he considered extending the provisions and the scope of President Kennedy's 1962 Executive Order 11063 on housing, and he was wary of acting precipitously. ${ }^{7}$ 
After Johnson's election in November 1964, A. Philip Randolph argued that extension of Kennedy's housing order was vital: "Housing is central to the whole field of civil rights and no amount of success in any single phase of the civil rights movement can be sustained as long as racial discrimination in housing persists." 8 Charles Abrams, president, and Edward Rutledge, executive director of the National Committee Against Discrimination in Housing (NCDH), which claimed to represent 60 million American citizens through affiliate organizations, wrote to the president: "It seems clear that discrimination in housing looms as the major civil rights issue during the coming decade." Abrams and Rutledge also called for an extension of President Kennedy's Executive Order 11063 as a "first step" in addressing housing discrimination in the United States. ${ }^{9}$ Others continued to exhort the president for immediate action. ${ }^{10}$

As early as December 1964, the Justice Department was exploring the possibility of extending President Kennedy's Executive Order 11063. The assistant attorney general for the Office of Legal Counsel, Norbert Schlei, explored requiring independent banks and savings and loans to abide by federal nondiscrimination policies in lending practices. According to Justice Department materials compiled in preparation for the 1968 Civil Rights Act, "Mr. Schlei concluded that such executive action might be attended by considerable legal and practical difficulties." By May 1965, Schlei also had determined that while the president, by means of executive order, did retain the power to prohibit banks and savings and loans from discriminating against borrowers (for example, African Americans and other minorities), "he thought it doubtful that the executive had the authority to require banks to impose nondiscrimination requirements on their borrowers." 11

By early 1966, then, attention focused upon developing legislation rather than on the use of the executive order. It was determined that a new omnibus civil rights bill would best accomplish what LBJ had in mind and perhaps, ultimately, serve as a useful vehicle to appease Congress as well as civil rights advocates. Johnson administration officials initiated plans for new legislation. Given their inherently controversial nature, such plans would require a good deal of persuasion if they were to be implemented effectively.

\section{LBJ's Presidential Persuasion on Behalf of Open Housing}

\section{6: Addressing "A Profound Hypocrisy"}

On April 28, 1966, Lyndon Johnson went before Congress to request additional civil rights legislation. The president announced the problem and the goal forthrightly: "[D] iscriminatory racial practices still exist in many American communities. They deny the Negro his rights as a citizen. They must be ended." 12 The president called for stronger federal statutes to punish those interfering with civil rights efforts, new 
procedures on jury selection to prevent discrimination, broader powers for the attorney general in efforts to press desegregation of public facilities and schools, and legislation that would bar discrimination in the sale or rental of the nation's housing. ${ }^{13}$ Ongoing attacks on civil rights activists had become open wounds to be cauterized. Therefore, the president recommended that $100 \mathrm{FBI}$ agents and support personnel be authorized "to deal with civil rights crimes." 14

Johnson argued that his aim was to establish "a more generous idea of brotherhood and a more responsible conception of equality." The president maintained that his goals were a "part of the unfinished business of every state." 15 While the president issued principled appeals to "brotherhood" and "equality," it was the economic reality underpinning civil rights legislation that was now erupting center stage. It did no good to guarantee human rights by law if people were neither fed, nor clothed, nor sheltered. These primary safety nets garnered the attention of both the president and Congress. An interdependent web of unequal relations, LBJ argued, had to be rooted out: "It is self-evident that the problems we are struggling with form a complicated chain of discrimination and lost opportunities.... All the links-poverty, lack of education, underemployment and now discrimination in housing-must be attacked together." 16

The key to the legislation, and the most difficult, however, was the housing provision. Johnson implored, "I ask the Congress to enact the first effective federal law against discrimination in the sale and rental of housing." ${ }^{\prime 17}$ The president argued that the time had come to move beyond President Kennedy's 1962 executive order; there was a dire need to be more inclusive than merely protecting governmentinsured housing programs. The goal was comprehensive: "end discrimination in all housing, old and new-not simply in the new housing covered by the Executive Order." Johnson proposed that his new legislation was necessary to "cover the sale, rental and financing of all dwelling units. It will prohibit discrimination, on either racial or religious grounds, by owners, brokers and lending corporations." The president's reigning rationale emphasized moral purpose: "As long as the color of a man's skin determines his choice of housing, no investment in the physical rebuilding of our cities will free the men and women living there."18

Johnson's call for federal housing legislation was interpreted as a hopeful sign by many in the black community. While the president's speech was both high-minded and pointed, subsequent material events would preclude a positive response to his urgent message. Several material constraints undermined LBJ's rhetorical efficacy, including the economy, anticipation of poor performance by the Democrats in the upcoming off-year elections, committed external opponents, disagreement among LBJ's closest advisers, and the newly released report "To Fulfill These Rights," which was produced under the auspices of the administration.

By 1966 inflation was tearing at the domestic economy and the Vietnam War was draining Johnson's energy and the nation's coffers. By March 1966 LBJ's approval 
rating had dropped to 56 percent, his lowest approval rating since $1963 .{ }^{19}$ The prospects for the Democrats in the off-year elections also looked bleak. Increased movement on open housing only promised to make a bad situation worse. ${ }^{20}$

If the internal political landscape looked bleak, it was even less attractive when the administration encountered angry, intractable external opponents. The open housing provision predictably raised the ire of real estate agents concerned with "property rights" and homeowners who felt it would inevitably lead to a loss of "property values." For example, presidential aide Clifford Alexander reported to Harry McPherson that Eugene P. Cosner, executive vice president of the National Association of Real Estate Boards (NAREB), was anxious to introduce the president personally to their newly elected leader. As Alexander described it, "The newly elected head, from my information, is, by their definition, a moderate. This means that he is completely against any federal legislation in the field of open housing, but would favor a voluntary program." 21 The new civil rights initiative announced in late April was, at best, proving unpopular in many quarters. Moreover, compromise bills were filling the House and Senate floors, threatening to water down the impact and long-term effect of the housing provision.

Even the president's own advisers were in basic disagreement about presidential endorsement of any proposed compromise. For example, Clark Clifford advised the president to stand firm: "Certainly the history of housing legislation in cities and states indicates that the piecemeal approach . . . has minimal effect on changing housing patterns. I therefore think we should stand firm on Title IV, which you originally sent to Congress." 22 Attorney General Nicholas Katzenbach disagreed, arguing that "half-a-loaf is better than none" and that "compromise will, if enacted, moot the cry for an Executive Order. Defeat of the housing title will increase those demands." ${ }^{23}$ Such conflicting advice did little to address the pressing need.

By late August 1966, the final report of the President's White House Conference, “To Fulfill These Rights," had been issued by A. Philip Randolph and Benjamin Heineman. The report's housing recommendations suggested that the administration's bill needed additional strengthening. Conferees recommended that Johnson forces: (1) use all available federal resources to implement equal opportunity housing; (2) enforce the existing housing order and Title VI of the 1964 Civil Rights Act; (3) require state licensing for mortgage brokers and builders; (4) expand the Demonstration Cities program; (5) continue the Rent Supplement Program until a more comprehensive approach could be implemented; (6) inaugurate a Housing Industry Program patterned after John F. Kennedy's earlier Plans for Progress; and (7) authorize HUD to purchase, lease, and sell land with the intention of providing housing for all (on a nondiscriminatory basis). ${ }^{24}$

Despite the constraining effects of the president's declining popularity, predicted off-year electoral losses, external opponents, conflicting internal advice, and a negative report on the administration's housing efforts, the Civil Rights Act of 1966, 
including the fair housing title, passed the House by an overwhelming vote. A majority of the Senate also favored the president's bill, but it came to the floor too late in the session to break a filibuster. Although Johnson failed to get his legislation adopted in 1966, he remained undeterred.

\section{7: A Year of Violence, A Year of Pain}

Johnson's February 15, 1967, message to Congress on "Equal Justice" was rhetorically consistent with his earlier pleading and as morally succinct:

Last year [1966] the legislation I proposed to ban discrimination in housing stirred great controversy. Although a majority of both Houses in Congress favored that legislation, it was not enacted. Some of the problems raised by its adversaries were real; most involved myths and misinformation. The summer riots in our cities did as much damage to the chances of passing that legislation as the unfounded fears of many Americans and the opposition of special interest groups.... I am proposing fair housing legislation again this year because it is decent and right. Injustice must be opposed, however difficult or unpopular the issue. ${ }^{25}$

Indeed, the president assured the Congress that his goal remained unchanged. He was interested in: "not just equality as a right and a theory, but equality as a fact and as a result." ${ }^{26}$ For Lyndon Johnson, these words seemed no less true in 1967 than they had in 1965. Despite the principled rhetoric, the president found no new slogan, no startling metaphor, no fresh rhetorical perspective to launch his renewed legislation. His reversion to words he had summoned in his Howard University address almost bespoke of a kind of "past glory." The president seemed to be in the awkward position of reaching back to press ahead.

In point of fact, this latest presidential message was largely interpreted as mere "ritual." After all, the measures for 1967 were largely the same as those proposed in 1966, and Johnson was perceived by many as merely trying to hold on to failed legislation. As one writer for Newsweek magazine observed: "This time . . Congress itself stood transformed at least in part by the white backlash—and less hospitable than ever to the cause of the Negro American. The president measured his words accordingly: his civil rights message for 1967 was not so much a clarion call to action as a plea to persevere." While the speech was judged as "not without its eloquent moments," it was predicted that "Congress, not the President, would overcome-and that the bill would languish into the campaign year of 1968 ." ${ }^{27}$ There are two circumstances that help explain this negative evaluation: Martin Luther King's newly announced opposition to the Vietnam War and continuing complexities associated with the summer urban riots. Each of these events directly impugned LBJ's leadership. 
The Vietnam War took its toll on the president's popularity and political viability. $^{28}$ It inevitably spilled over to his domestic agenda. LBJ felt his housing provision would be the linchpin of any significant civil rights act. Time and again, LBJ displayed his sympathy with the plight of African Americans, especially those who were serving in Vietnam. Indeed the president had publicly stated numerous times that there was a marked inconsistency between fighting for freedom abroad and the inability to exercise basic freedoms at home, such as free choice in housing. By April 1967, however, there was a new tension between Johnson and civil rights advocates. Martin Luther King had publicly and forcefully declared his opposition to the war in Vietnam. ${ }^{29}$ This declaration threatened to split the civil rights movement internally, angered the president and other liberals who were struggling to provide more civil rights legislation, and gave the enemies of civil rights additional grounds for an already virulent opposition. Thus, King's opposition to Vietnam tended to overshadow Johnson's housing initiative, weakened its support, and buoyed the opposition. For Lyndon Johnson, it was as if Martin Luther King, Jr. had inexplicably lobbed a Molotov cocktail into the Oval Office. Given these developments, and the direct challenge they posed to the president's leadership, LBJ's motivation to pursue a third major civil rights bill might well have been enervated. A confidential FBI report summarized at least part of the concern raised in this turn of events: "In the long run, the consolidated civil-rights-peace movement will be detrimental to the national security and the best interests of the nation, for it will not only tend to encourage the enemy and prolong the Vietnam war but will also have an adverse effect on the cause of civil rights." 30 The potential for a new public alliance between peace protesters and civil rights advocates also signaled an ominous new period of strained relations between the president, civil rights advocates, and the Congress. None of this boded well for the 1967 housing bill. King's opposition to the war angered the administration and was viewed as disloyal. It is possible that King's action dampened the president's resolve to press forward on the bill. The conflict with King, however, was probably much less threatening to the president's new civil rights legislation than the annual urban conflagrations, which impugned Johnson's leadership, sorely tested national comity, and led to increasing calls for stricter laws to control the widespread violence. ${ }^{31}$

A succession of summer riots during the president's tenure was central to growing negative perceptions of his leadership. ${ }^{32}$ As they steeled for another summer of social unrest, administration officials sought to avert a potential race war, growing division, and a virulent white backlash. Simultaneously, the statistics on racial inequality continued to mount. ${ }^{33}$ Many Americans and their representatives in Congress also anticipated another summer of violent disturbances and they were in no mood for a civil rights package that would in any way signal compromise with violent forces. In this time of crisis, many felt that giving in to "Negro demands" meant courting continued anarchy and violent division. Such people took a "lawand-order-first" approach to the problem. 
As predicted, summer violence broke out in both Newark and Detroit. ${ }^{34}$ Johnson referred to the riots as "civil disorders." From the vantage point of detractors, the president was merely employing a euphemism that masked an intractable problem. At a minimum LBJ was on the horns of a significant dilemma. As P. H. Zernicke described it, "The President could neither condone civil disobedience nor condemn the legitimate grievances of black Americans." 35 White America demanded that the president exercise his constitutional mandate to "preserve domestic tranquility." Simultaneously, LBJ, who seemed "genuinely sympathetic" to the black plight, was also desirous of maintaining black and white political support. This desire, which was "consistent with Johnson's pursuit of personal affection and presidential immortality," was not necessarily easily achieved. ${ }^{36}$

In the president's view, the urban ghettoes had become seething cauldrons of neglect, despair, and unrest. LBJ was convinced that the summer violence was a direct outcome of the misery and poverty at the core of the nation's urban centers. ${ }^{37}$ Johnson seemed unsure as to why his earlier initiatives had not stemmed the tide, or at least led to notable amelioration. On July 27, 1967, the president announced the appointment of the Kerner Commission, which had as its charge to investigate the causes of the urban violence and to suggest remedies. This move was intended as a gesture of presidential action. Some advisers felt such an advisory panel also might help soften expected congressional investigations into the riots and buy more time for a variety of LBJ's urban aid programs.

The riots continued their negative effect on public attitudes toward race relations in general and housing in particular. Fred Panzer informed the president that August 1967 poll results revealed that "[b]asic white attitudes toward integration in housing have not changed since 1963. But close to one out of three white persons now have a lower regard for Negroes because of the recent riots." 38 Lyndon Johnson felt he had no choice but to move more legislation forward. Indeed, by August 1967 the administration had become convinced that "existing proposals for model cities, housing, and crime control bills could improve inner-city life and prevent riots." 39

In sum, the summer riots that had followed a tempestuous spring made LBJ's legislative task even more difficult. The images of cities aflame, looting, and a general feeling of lawlessness had also had a stiffening effect on both congressional and public attitudes toward advancing civil rights. In the context of the times, many people seemed unwilling to, in their view, "reward" blacks for violent activity. Congress, for its part, did not want to be perceived as kowtowing to militant demands. Many sectors of the public joined with congressional leaders to demand that "order in the streets" be restored before making any further attempts either to integrate or to improve urban neighborhoods.

Public opinion and congressional support sagged under the weight of an expensive and unpopular war abroad and urban violence at home, both of which drained the little lifeblood left of a flagging Great Society program. Thus, both the riots and 
the war militated against LBJ's popularity, if not his grand ambitions. These two political "problems" were certain to affect the 1968 elections. By the summer of 1967, "Johnson's presidency was being torn at both ends." 40

As in 1966, the 1967 housing measure remained the most contentious part of the administration's attempted civil rights measures. The housing provision cut to the bone. Marching in the streets to obtain justice was one thing-requiring Americans to live in colorblind neighborhoods by law and attempting to integrate individual homes and rental properties through the imposition of federal legal sanctions were, for many, quite another. The proposed package for 1967 fared no better than the one offered in 1966. The housing portion of the bill still remained its Achilles' heel. Johnson had barely delivered the speech introducing the legislation when Fred Panzer observed: "I have been informed by HUD that the National Association of Homebuilders will be silent or unhappy over the Equal Justice Message. Reason: They are concerned about the gradual approach in ending housing discrimination. They fear it hurts their members' competitive position in the housing market." 41

When the 1967 omnibus civil rights bill made little headway, it was decided to break the bill up, especially because of the intense pressure to legislate control in the streets. Congress was wary of even a "diluted" open housing provision and of provisions protecting civil rights workers at the expense of the individual states. Most members were most intent on the need for an anti-riots bill as an attachment to the omnibus legislation. None of this, however, was accomplished. In essence, the 1966 civil rights initiative failed and most of 1967 was spent trying to revive it. ${ }^{42}$

\section{8: Another Civil Rights Message and the King Assassination}

The preparations for yet another civil rights address came on the heels of Lyndon Johnson's annual State of the Union address, wherein he pledged to mount yet another attempt at civil rights legislation. Only one week after delivering his message on the state of the nation, the president, in his January 24, 1968, "Special Message to Congress on Civil Rights," announced he would send legislation to the Hill intended to protect civil rights advocates, increase the enforcement powers of the Equal Employment Opportunity Commission (EEOC), remove discrimination in federal and state jury systems, and finally, achieve fair housing and a larger national housing stock. ${ }^{43}$ LBJ also pledged to send Congress a $\$ 1$ billion Model Cities program and a plan for a "ten-year campaign to build six million new decent housing units for low and middle-income families." Arguing that the mere construction of new housing was "not enough — unless every family is free to purchase and rent them," the president also reaffirmed his unwavering desire to combat discrimination in housing: "Every American who wishes to buy a home, and can afford it, should be free to do so." 44 
Announcing a controversial staged policy implementation similar to earlier failed attempts, the president said his effort would be directed at all housing and rental units in the United States and would be applied in an orderly fashion: First, immediately to housing covered by John Kennedy's earlier executive order, then to dwellings sold or rented by non-occupants and to units housing five or more families, and finally to all housing stock in America. The proposed legislation would cover discriminatory practices in financing, bar "block-busting," and be enforced by HUD (Department of Housing and Urban Development) and by the Justice Department in the person of the attorney general..$^{45}$ The president tried to frame public expectations in accordance with his own view of the situation: "A fair housing law is not a cure-all for the Nation's urban problems. But ending discrimination in the sale or rental of housing is essential for social justice and social progress." ${ }^{46}$ When adopted, the legislation would cover approximately 80 percent of all U.S. housing stock.

The president was well aware that he was on the horns of a dilemma. The summer 1967 riots had further vitiated the rationale and congressional clamor for extending civil rights. Johnson faced this nemesis directly: "Lawlessness must be punished-sternly and promptly. But the criminal conduct of some must not weaken our resolve to deal with the real grievances of all those who suffer discrimination. Nothing can justify the continued denial of equal justice and opportunity to every American." ${ }^{47}$ Johnson was persistent in his appeals to principles of justice, equality, and social progress; he seemed determined not to let the violence deter his legislation.

Cognizant of calls for law and order and anxious to protect the rights of civil rights workers and those they worked with, and equally aware of the delicate political terrain yet to be traversed, LBJ engaged in negotiations with the Senate. While the House had passed a relatively toothless civil rights bill in the summer of 1967, there was a bit more progress with the 1968 Senate. ${ }^{48}$

The NCDH hailed Johnson's "forthright and practical message" and praised him for incorporating "the two essential elements in any program to solve the nation's housing dilemma: A massive increase in the supply of decent housing for the masses of Americans, and guaranteeing under law equal access to housing throughout the market." ${ }^{49}$ National Association for the Advancement of Colored People (NAACP) Washington Bureau Chief Clarence Mitchell, credited by many as the point man on LBJ's legislation, praised Johnson's message, but warned: "Each delay in consideration of these vital bills is a moment of peril for the nation's reputation for fairness and justice." 50

As was its usual custom, after introducing the legislation with the impetus of a presidential speech, administration aides immediately went about the intricacies of trying to ensure its passage. This meant trying to shape disparate forces toward successful enactment. On February 13, 1968, Mike Manatos informed the president that 
Senator Mike Mansfield was determined to dispose of the civil rights bill "one way or another" by the end of the week. Manatos was anything but serene regarding the outcome: "Unless he can work out some sort of compromise with Senator [Everett] Dirksen, which now seems unlikely, he intends to move for cloture on Monday. If cloture fails it is his plan to lay the bill aside and to proceed with other Senate business." ${ }^{51}$ By February 17, 1968, both Ramsey Clark and Walter Mondale had urged the president to make a statement on the upcoming Senate vote. On February 19, the president sent a public letter to Senator Philip A. Hart urging that the Senate pass his bill. ${ }^{52}$ On February 20, 1968 Ramsey Clark, in an upbeat mood, wrote the president: "We are ... very close to a major civil rights achievement." ${ }^{33}$ As Time magazine noted, "[A] Republican-Democratic liberal coalition, improbably abetted by Minority Leader Everett Dirksen, pushed through the open housing provision and sent the much expanded package back across Capitol Hill to the House."54

Indeed, after a successful Senate vote of 71 to 20 on March 11, 1968, Johnson, for his part, wrote a letter to House Speaker John McCormack urging prompt action. Johnson was particularly mindful of the need for the housing portion of the omnibus legislation. The president invoked an increasingly familiar argument as one of his rationales for passing the legislation:

To one man - the Negro veteran of Vietnam - the fair housing provision will have a special meaning. I do not need to tell you what he has done for our country. It is up to us-to all of us-to assure him the elemental rights in his own country for which he risked his life overseas. That man —and his race-are entitled to the justice this bill provides. ${ }^{55}$

Evidence of Johnson's commitment is reinforced in the encouragement he directed at the NAACP's Clarence Mitchell: "I know how hard you worked-and still must work, to assure the final adoption of this landmark bill. Its passage is essential from every practical and moral point of view. Its friends must not rest until it becomes the law of the land." 56

The administration debated how best to hoist its bill over some dangerous hurdles. In particular, there was a row over whether the bill should be sent to conference committee, where it had the potential to be significantly watered down or buried, or whether the bill should be sent directly to the House floor where there could be a swift vote to concur with the Senate version that had already passed. ${ }^{57}$ As the machinations in the House of Representatives over the omnibus bill continued, a profound series of events was about to rearrange the political landscape in America yet again.

On March 31, 1968, Lyndon Johnson shocked the nation with his announcement that he would not seek another term as president of the United States. While Johnson may have ascribed his decision to reasons of health and as a selfless, last-ditch 
attempt to bring the conflict in Southeast Asia to a conclusion, some felt that the war in Vietnam had finally broken the spirit of this seemingly indomitable man. ${ }^{58}$ Regardless of the motivation for LBJ's withdrawal, brokering any new legislation would now be more difficult. Days later, yet another bombshell would shatter the nation and splinter hopes for accord in race relations.

Martin Luther King was assassinated on April 4, 1968. This event provided the president with a unique rhetorical challenge and it was strewn with potential land mines. The president went on national radio and television to deliver a brief eulogy asking Americans to pray for peace and to end "lawlessness and divisiveness" in the land. ${ }^{59}$ The next day the president addressed the nation in more detail, trying to soothe hearts and minds that were now fully roiling over King's death. The president also tried desperately to find words to help quell the civil disturbances: "The life of a man who symbolized the freedom and faith of America has been taken. But it is the fiber and fabric of the Republic that is being tested." LBJ called upon all Americans to "deny violence its victory in this sorrowful time and in all times to come." The president issued a special proclamation and ordered the flag flown at half-mast in tribute to King and as a sign of national mourning. Johnson promised to call a joint session of Congress and to deliver a message with "suggestions for action" no later than the following Monday. LBJ's intent was clear: "We must move with urgency, with resolve, and with new energy in the Congress, in the Courts, in the White House, the statehouses and the city halls of the Nation, wherever there is leadership ... until we do overcome." The promised message was postponed in light of ensuing events. ${ }^{60}$

From April 4 through April 11 a rash of violent outbreaks engulfed a host of U.S. cities. The president had to issue a special order to restore law and order in Washington, D.C. Even the nation's capital was a site of seemingly profound insurrection. The King assassination and the civil disturbances that followed threatened to place a sizable crimp in the president's plans to achieve a third major civil rights act during his administration. ${ }^{61}$

The president received much advice as to how to handle his response to the King assassination and the riots that immediately followed. As the president and his staff wrestled with the attendant problems, a number of complicated decisions loomed in LBJ's fight for the Civil Rights Act of 1968. The situation was extremely delicate. The administration had to act, but it could not be perceived as "giving in" to the forces of violence.

From the vantage point of White House aides, any public presidential reaction to the King assassination and its fiery wake called for tact in public relations, political savvy, and spin control. Having already eulogized King, proclaimed a day of national mourning, and appealed to the nation to recultivate its traditional sense of law and order, the problem now was how to save the president's legislation and simultaneously contain a smoldering national urban rebellion. This was a tall and complicated order-especially with smoke still billowing over the nation's capital. 
The immediate challenge Johnson faced-and had to solve quickly—was deciding among a bevy of incoming but differing perspectives and recommendations. Whatever LBJ might decide, administration officials were unanimous in the opinion that it had to be something profound and dramatic. They planned to address the American public on the riots but worried over content, timing, and effective alternative ameliorative actions. There was also the matter of the King funeral, which they now knew would impact both the symbolic political environment and the timing and strategies adopted on the legislative process.

On April 5, Ben Wattenberg advised the president that his contacts felt that it was in the president's interest to meet with black power advocates, outline his new proposals, and ask them to help him implement his initiatives, especially on housing. In addition, Wattenberg cited "an intense need for symbolic acts by the President." Wattenberg, however, advised caution in that a meeting with black power advocates could have "explosive aspects to it." ${ }^{2}$ Ed Wynne of the Office of Education suggested that the president declare in his planned address that an annual day be set aside to honor slain civil rights leaders and that Johnson should announce that there will be a monument built in their name. Since these martyrs were both white and black, such a symbolic action would emphasize civil rights as "an American struggle for American ideals, just as Valley Forge was." 63

On April 6, Fred Panzer informed Johnson that Lou Harris suggested that prior to any legislation an appeal should be made to the populace to "deposit their guns at their churches." In addition, Panzer called for detailed anti-riot laws for inclusion in the 1968 Civil Rights Act, including federal legislation against shooting at firefighters. Panzer, looking for "symbolic reassurance" for a shocked and aroused citizenry, felt the white community would be most pleased if Stokely Carmichael were arrested by Walter Washington because "it would symbolize that black power extremists do not represent the vast majority of Negroes." Panzer also advised LBJ to stress the need for his open housing provision, to ask Congress to pass his bill within 72 hours, and to seize the moment by "introduc[ing] something dramatic." Perhaps, Panzer mused, now was the hour to mount a "drastic program for the lost generation of ghetto children and teenagers" who were seen in many of the televised images of rioting. As "players in the carnival of looting," they remained "the tinder of civil disorders." Therefore, Panzer argued: "There must be some way to remove them from the scene-for their own sake as well as society's. In other words can the government do for them what rich parents do for their children, i.e., send them to prep schools, summer camps, etc." 64 The president's political instincts must have been simultaneously engaged and shaken by such advice. Despite the agony of another national assassination, a political opportunity had presented itself. In the Johnson administration such an opening suggested one obvious and habitual tack: exploitation by all necessary means.

Clifford Alexander cautioned the president to use "firmness" against the rioters and looters. He told the president that Mayor Washington and others ought to 
appear on local television every half hour to announce that "looters will be handled with immediate but reasonable force," and to affirm publicly the fact that while the administration was responding with reason, additional force might be necessary to restore order. Alexander, echoing Panzer's sentiments, also told the president "we have plenty to arrest Carmichael on and should do so immediately and be sure he is put in a jail outside of the District." Finally, Alexander felt the "vast majority" of the black populace would endorse increased riot control measures because they also knew-better than anyone else-that after their neighborhoods were destroyed "nobody [wa]s going to go in and build [them] up [again] on the assumption that [they] will be burned down again soon." 65

Albert Cantril of the State Department, cognizant of international ramifications, suggested that Roy Wilkins draft the president's address. He also advised that the global audience be informed "that the rioting was not white against black but was basically the work of teenage hoodlums." Cantril counseled the president to divide his talk into three sections addressing whites, blacks, and all Americans. Finally, he observed: "There is no better eulogy than to quote extensively from King himself. The president could do this at considerable length." The latter two points were not attractive to Fred Bohen. Bohen observed: "The President's task is to make people believe and act as one nation, and the speech should be his speech and his quotes for history, not Dr. King's, as eloquent as they were." Bohen passed Cantril's message to Harry McPherson for his "burgeoning file." 66

Meanwhile, administration officials continued preparations for what aides now labeled the president's "Riots Speech" and tentatively scheduled it for Tuesday, April 9, 1968. HUD Secretary Robert Weaver drafted some remarks he hoped the president would incorporate into his anticipated upcoming address. He felt the president should include four major points:

1. The time is right to consider reordering the national priorities. Any appeal to Congress for increased funding should be accompanied by such a declaration. Space and highway programs, the SST, and certain non-essential defense expenditures should be re-examined in the light of present exigencies.

2. Negro Americans should not blame the foul deed of one deranged man on all whites any more than white America should blame all Negroes for current lawlessness.

3. The lack of neighborhood outrage against lawlessness is to be deplored. We must work to create a sense of outrage in America against lawlessness and injustice. Congress must pass measures already approved by the President to deal with crime in the streets.

4. Militancy in America arose because the nation has failed to deal effectively with discrimination and deprivation. This the Kerner Commission appropriately and rightfully identified. We have made progress, but it has not been enough. 
Weaver wanted the president to employ these four points as arguments for passing his 1968 civil rights bill, initiating immediate employment and training programs, and enacting the wide agenda of programs the president had on his plate, including poverty, health, education, housing, and urban development. The fact that more monies would be directed toward Weaver's agency was an effective outcome, if not the goal of this line of argument. So even in the poverty of social strife, the machinations of power continued to churn. Weaver also asked the president for an opportunity to comment on the draft of the proposed speech. ${ }^{67}$

As previously indicated, however, the flurry of activity regarding the need for an additional strong nationwide symbolic statement by the president went for naught in the onslaught of ongoing events. It was Lyndon Johnson, however, who helped shape the rhetorical construction of those events and, in the process, influenced the legislative outcome. An argument for Lyndon Johnson's rhetorical opportunism follows. To make that argument clear, let us return to the president's public address immediately following the King assassination.

Recall that on April 5, President Johnson addressed the nation and declared a national day of mourning for Dr. King. In that address LBJ deliberately tried to influence public opinion on the need for swift passage of his newest civil rights initiatives. The president carefully crafted a rhetorical appeal conducive to his ends. First, he had to respond to the outbreaks of violence and the forces of violence in the nation that compelled them: "The dream of Martin Luther King, Jr. has not died with him. Men who are white-men who are black-must and will now join together as never in the past to let all the forces of divisiveness know that America shall not be ruled by the bullet, but only by the ballot of free and just men." Next, he would extol the progress already made in civil rights, but argue that there was more left to do that could be done: "We have rolled away some of the stones of inaction, of indifference, and of injustice. Our work is not yet done. But we have begun." The scene of action of most import would be in the halls of Congress: "We must work with urgency, with resolve, and with new energy in Congress . . . until we do overcome." The president announced that he would soon deliver an address that would outline a number of forms of "constructive action." This would give him the opportunity to press for his civil rights bill and go beyond it to expand additional areas in need of attention. ${ }^{68}$ As things turned out, that address was never delivered. What Johnson could not deliver by formal public address, he would deliver by personal and other forms of public persuasion.

Ever the opportunist, the president acted immediately. The very same day LBJ declared a national day of mourning for King he sent a letter to House Speaker John McCormick, which appealed for passage of the fair housing bill. This appeal was premised upon the changed circumstances occurring with the onset of King's assassination. The president reminded the Speaker of his earlier March 11 entreaty for open housing legislation. The bill, having been waylaid in the House, argued 
Johnson, was now more important than ever in the wake of the King assassination. The president was direct:

Last night America was shocked by a senseless act of violence. . . . This tragedy has caused all good men to look deeply into their hearts. When the Nation so urgently needs the healing balm of unity, a brutal wound on our conscience forces upon us all this question: What more can I do to achieve brotherhood and equality among all Americans? . . . There are many actions the Congress can take, on its part. The most immediate is to enact legislation so long delayed and so close to fulfillment. We should pass the Fair Housing law when Congress convenes next week. ${ }^{69}$

The text of the letter was distributed to news reporters and the public. Thus, Johnson blatantly pressed his newest rhetorical rationale for passing his civil rights legislation: "King is dead and America is aflame: we need action now!"

LBJ positioned successful passage of his pending legislation as a mode of transcendence, a political curative that would solve a social problem. ${ }^{70}$ According to Kenneth Burke, transcendence is a rhetorical strategy that allows the rhetor to symbolically endow a person, place, object, event, or set of circumstances with "a new identity." "71 Burke also observes that "transcendence involves a new motive discovered en route."72 The rhetoric of transcendence is adopted by the rhetor as a means of advancing a "purified perspective" on events and circumstances in a direct effort to overcome symbolically perceived negative manifestations. ${ }^{73}$ To achieve transcendence the rhetor must find a means of "negating the negation." 74 For example, a "trial by fire" can be rhetorically transformed into a "transcendent burning, light."

In the case of Lyndon Johnson, civil rights legislation is presented as a means of "ritual purification" intended to ameliorate the death of Martin Luther King and the ensuing riots. Johnson represented his legislation symbolically as the best and most concrete mode for healing division in the social hierarchy. Civil rights legislation was positioned and argued as something that went beyond a tribute to King; it was a modality for meeting the present crisis and getting the nation "beyond" an inexplicable tragedy. In making this argument to Congress, LBJ turned from principled idealistic argument based on fairness, equality, and social progress to that of the pragmatic and practical. By arguing that his legislation was the best solution to the problem at hand, the president helped forge a strong logic for his housing legislation, its impetus impelled by an argued need for immediate action. This tactic, intentionally selected and scrupulously applied, served LBJ well. Thus, Johnson's rhetoric of transcendence allowed him, in Kenneth Burke's words, to "transcend' the sheerly empirical events of ... the times" through linguistic transformation. ${ }^{76}$

Congress, for its part, which had indeed long languished on this bill, reacted with the swiftness Lyndon Johnson had demanded. The King assassination had shifted the political alignments. For example, William McCulloch, the ranking Republican on 
the House Judiciary Committee, broke ranks with House Republican leader Gerald Ford, who opposed the bill. Illinois's John Anderson did the same, followed by more than a dozen other Republicans. Given this changed political terrain in the wake of the King assassination, Johnson was confident that he probably had enough votes to overcome opposition in the House. He decided to cancel his "constructive action" or "riots" speech in an effort not to antagonize the new converts by seeming to take sole credit for the bill and other proposed curatives. He now judged he had a critical mass of bipartisan support for new civil rights legislation within his grasp, and he was determined to say nothing that might upset it. In this instance, Johnson had abandoned public words to press for deeds — and his strategy was highly successful. ${ }^{77}$

Meanwhile the violent outbreaks in America continued. On April 6, the acting governor of Illinois requested federal troops to quell disturbances in Chicago. On April 7, the governor of Maryland requested federal troops to protect Baltimore. ${ }^{78}$ On April 10, 1968, the House voted to concur with the Senate bill, which meant that Congress had formally passed the Civil Rights Act of 1968. In a news conference that same day, the president reflected: "It has been a long, tortuous, and difficult road." 79 As Johnson observed: "A few years ago when we met here in the White House and discussed open housing and how to handle it by regulation or statute, there were very few who thought that in our time we could bring this justice to all Americans. But the Congress today has shown that if we have the will, there is a way." 80 The president had the will and he was determined to find a way. Harry Middleton, a Johnson confidant and the speechwriter for the 1968 Civil Rights Act signing ceremony statement, acknowledged that Johnson "intentionally" used the King assassination as a means of achieving his long-delayed housing legislation. ${ }^{81}$

Even the symbolic rituals associated with the passage of the 1968 act were politically charged. Johnson had once again acted on behalf of African American civil rights but, in the aftermath of the civil unrest associated with the King assassination, there remained suspicions as to whether his actions and those of Congress had been taken under duress, if not coercion. On April 10, 1968, Barefoot Sanders informed the president that Clarence Mitchell was advocating a signing ceremony for the civil rights bill, even if it involved delay in enactment. In affirming this request, Sanders observed: "I agree with Clarence. The Open Housing bill is an accomplishment that no one thought obtainable. We should have a signing ceremony in order to focus attention on it. Further, it seems to me that if the President signs the bill in a hurry without a ceremony that the impression may be left with the public that the bill is being rushed into law in response to the recent riots. That would be an erroneous impression." 82 Erroneous or not, at the signing ceremony on April 11, the president observed: "[T]his bill has had a long and stormy trip." Nevertheless, Johnson took some comfort: "with this bill, the voice of justice speaks again." Indeed, the president did not seem to unduly boast in stating: "I think we can all take some heart that democracy's work is being done." ${ }^{83}$ But many felt it took 
the death of King and an incredible amount of national unrest to nudge the democratic spirit along.

\section{LBJ, Public Policy, and the Rhetoric of Transcendence}

Wayne Fields, commenting on the president's propensity for rhetorical leadership, observes: "No president in recent history has more blatantly tried to bend the country to his own will than did Lyndon Johnson." 84 As George C. Edwards has indicated, a president must lead the public, set priorities, and exploit opportunities. ${ }^{85}$ The 1968 Civil Rights Act demonstrated President Johnson's penchant to "bend the country to his own will" and to exercise leadership in word and deed, but it was also an exercise conducted in the wake of intense national mourning and division. Given these circumstances, it is hardly surprising that Lyndon Johnson's final major attempt at civil rights legislation was mired in controversy.

The president displayed persistence, adaptability, and opportunism in his quest for victory. First, he refused to let the housing legislation die, even after experiencing two defeats in Congress. Second, he, along with his administrative staff, tinkered with the provisions in an effort to make them acceptable to an inhospitable Congress. Third, LBJ consciously and calmly transformed the King assassination into a rationale for passing legislation that included his housing provision. Here, I believe we uncover a uniquely Johnsonian rhetorical pattern - the use of rhetorical transcendence as a mode of argument for public policy. Fourth, by canceling the "riots speech," the president displayed judicious rhetorical restraint; in the process he assured himself a legislative victory. Both discourse delivered and discourse suppressed are important components of compromise and success in the presidency. There was a delicate balance in need of observance and it was one that Johnson followed by both predilection and design. Spoken and unspoken words are acts of leadership. When executed well, they can subsist as the sign and substance of indelible deeds. Traditionally deeds are looked upon as primary. But as we have seen, deeds also require rhetorical framing. From the policy side of the equation, on the open housing issue in particular, the president demonstrated a "persistent commitment ... long after most of his advisers suggested that he give up." 86

History and rhetorical invention often provide opportunities for unique appropriation. It was Johnson's rhetorical genius to interpret and orchestrate historical events as opportune moments for public arguments on behalf of legislative change. As Bornet "reluctantly" observes, all of the civil rights legislation passed in the 1960s "was accelerated by acts of violence." ${ }^{87}$ The rhetorical challenge was to find the proper appeals in such an inflammatory environment. History dealt Lyndon Johnson a series of violent circumstances that he rhetorically transformed from Good Friday events to Easter Sunday celebrations. Such a complicated rhetorical feat required legislative and rhetorical compromise. It was patently obvious that the riots following the King 
assassination made the law and order provisions of the civil rights bill sacrosanct. Both LBJ and Congress were not about to give up on civil order. They were both willing to extend civil rights, but not without the civil order provisions securely in place.

Many came to view the fair housing bill as an "act of atonement" for the King assassination. ${ }^{88}$ I believe, however, that Johnson's arguments were premised on slightly different, but certainly related grounds. During his entire presidency Johnson utilized a series of tragic historical events to gain political advantage. While Johnson's encounter with tragic history yielded the Good Friday-Easter Sunday rhetorical stratagem employed after the King assassination, it was anything but an anomaly. In fact, there is evidence of a distinct pattern in LBJ's response to tragedy in his public address. More than a simple matter of atonement, this recurring pattern of rhetorical invention demonstrates the linkage between rhetoric and public policy. Time and again, LBJ inextricably linked word and deed by representing legislation as an act of public transcendence that would redeem the nation. New laws were presented as palpable means of national recovery.

In 1963, Johnson mourned President Kennedy with the theme: "Let us continue." He stated: "The greatest leader of our time has been struck down by the foulest deed of our time." Johnson referred to many of JFK's “dreams," which had been "vitalized by his drive and by his dedication": "Above all, [was] the dream of equal rights for all Americans, whatever their race or color." And Johnson would transform Kennedy's assassination into a rhetorical opportunity of political consequence. Johnson created and argued a means of national transcendence by insisting on present action: "Our most immediate tasks are here on this Hill. . . . no memorial oration or eulogy could more eloquently honor President Kennedy's memory than the earliest possible passage of the civil rights bill for which he fought so long." Early passage of that bill and his pending tax bill, LBJ argued, would "continue the work of President Kennedy." Not coincidently, it would also further LBJ's own goals and ambitions. These words were precursors to the Civil Rights Act of $1964 .{ }^{89}$

In like manner, Johnson's creative powers of rhetorical invention helped shape political opportunity in the passage of the Voting Rights Act of 1965. In a statement decrying the violence encountered in Selma, on the infamous Edward Pettus Bridge, the president observed: "I am certain Americans everywhere join in deploring the brutality with which a number of Negro citizens of Alabama were treated when they sought to dramatize their deep and sincere interest in attaining the precious right to vote. The best legal talent in the Federal Government is engaged in preparing legislation which will secure that right for every American." 90

Four days later, at a March 13 press conference, Johnson intoned: "This March week has brought a very deep and painful challenge to the unending search for American freedom. ... But the final answer to this problem will be found not in armed confrontation, but in the process of law." Furthermore, Johnson argued that Selma represented "a much larger meaning"; it was, in fact, "a protest against a deep 
and very unjust flaw in American democracy itself." Indeed, the constitutional right to vote was being denied and this denial required rectification: "Ninety-five years ago our Constitution was amended to require that no Americans be denied the right to vote because of race or color. Almost a century later, many Americans are kept from voting simply because they are Negroes. Therefore, this Monday I will send to the Congress a request for legislation to carry out the amendment to the Constitution." For the president, "What happened in Selma was an American tragedy" that simply "strengthen[ed] the determination of each of us to bring full and equal and exact justice to all our people." ${ }^{\text {"1 }}$ LBJ rhetorically reconstructed Selma as a symbol of a "tragic flaw" in American character and democracy, and he transformed this reference to place and space to a clarion call for "full and equal and exact justice" through legislation.

On March 15, when Lyndon Johnson introduced his legislation for the Voting Rights Act of 1965 to a joint session of Congress, he not only compared Selma to other hallowed grounds where blood had been shed in freedom's cause, he also reiterated that the solution to Selma and the continued cause for hope and progress in the future certainly were earmarked by this piece of important legislation: "There is no cause for pride in what has happened in Selma. There is no cause for self-satisfaction in the long denial of equal rights of millions of Americans. But there is cause for hope and faith in our democracy in what is happening here tonight." 92

Finally, on August 6, 1965, at the signing ceremony for the Civil Rights Act of 1965, Lyndon Johnson reiterated the meaning of Selma and his proposed "cure":

Last March, with the outrage of Selma still fresh, I came down to this Capitol one evening and asked the Congress and the people for swift and sweeping action to guarantee every man and woman the right to vote. In less than 48 hours I sent the Voting Rights Act of 1965 to Congress. In little more than 4 months the Congress, with overwhelming majorities, enacted one of the most monumental laws in the entire history of American freedom. ${ }^{93}$

A similar rhetorical pattern of rhetorical transcendence through legislation is evident in Johnson's response to the assassination of Robert Kennedy, which occurred approximately two months after Martin Luther King's. In this instance, LBJ sought viable federal laws regulating gun control. In an address to the nation following the assassination attempt (RFK had not yet succumbed to the assassin's bullet), Johnson issued a prophetic proclamation: "A nation that tolerates violence in any form cannot expect to be able to confine it to just minor outbursts." Therefore, Johnson resolved: "Let the Congress pass laws to bring the insane traffic in guns to a halt, as I have appealed to them time and again to do." ${ }^{94}$ The next day, June 6, LBJ sent letters to both the Senate and the House expressing the need for legislation. The letters referred to the earlier "mail order murder" of John F. Kennedy 
and declared that " $t \mathrm{t}]$ he voices of the few must no longer prevail over the interests of the many." 95

Thus all the major tragic events in the Johnson era, save perhaps Vietnam-the two Kennedy assassinations, the violence of Selma, and the King assassinationwere forcefully interpreted by Lyndon Johnson as unique, historically ordained inventional sites for rhetorical transcendence. For LBJ, in both rhetorical and political terms, transcendence was dependent on legislative action - be it the extension of civil rights or gun control. By both word and deed, Johnson imbued the nation with a distinctly hopeful sense that, despite the violence and the seeming chaos of the day, there were palpable means of recovery and redemption-and those measures could be codified into law. Johnson forcefully reconstituted the meaning of events and then shaped the words to match the required action. On idealistic grounds, Johnson argued for material change. In this instance justice that could not be codified was justice denied. In some ways this rhetorical-political tactic may have been part of Johnson's Achilles' heel. The legislation that was enacted raised hopes while simultaneously dashing them when the law could not or did not go far enough to protect civil rights, civil rights workers, and the quality of life of the nation's poorest citizens.

Harvard Sitkoff was skeptical of the efficacy of the actual civil rights legislation that received congressional approval in 1968: "[T] he measure had impossibly weak enforcement provisions, and placed the burden of combating racial discrimination on individual litigants. In addition, the law appeased, even pleased, the white majority by making incitement to riot a serious federal offense." 96 The law also did not prevent federal funds from being used to support segregated housing in the years that followed. The 1968 Kerner Commission report scored the federal government's public housing program on this very point. Another study by the U.S. Commission on Civil Rights appearing in 1970 identified equal housing as a "persistent problem." ${ }^{\text {" }}$ HUD apparently intended a very vigorous administration and enforcement of the 1968 Civil Rights Act but was undermined by Congress, which appropriated only $\$ 2$ million of the $\$ 9$ million requested for such purposes for the first year. ${ }^{98}$ Nonetheless, given the fractious conditions attending this protracted struggle, the president's legislative triumph has also been judged, in Steven F. Lawson's words, "a significant feat"-accomplished under some of the most trying conditions in race relations in our nation's history since the Civil War. ${ }^{99}$

\section{Conclusion}

President Johnson had started his campaign for fair housing in earnest in April 1966. Two years later, his efforts finally came to fruition. Johnson had tasted two bitter, although not entirely unexpected, defeats before indulging in the fruits of victoryand it proved to be an unlikely victory - captured by a lame-duck president from the 
South during a week of grief and national riots following the death of Martin Luther King, Jr. In a cold, calculated, yet humane way, Johnson used King's death, the ensuing riots, the continuing tumult of events, and the universally acknowledged rotting core of the nation's cities as a warrant to press human rights where no president had gone before. As Wayne Fields declares: "Johnson went farther than any other previous president to legitimate the civil rights cause, defending even more than its morality its consistency with national values and traditions." 100

The 1968 Civil Rights Act was perhaps an even more remarkable demonstration of presidential persistence than the two prior Civil Rights Acts in 1964 and 1965. While the 1964 Civil Rights Act may have had more symbolic influence and the 1965 Voting Rights Act may have had more lasting political significance, the 1968 Civil Rights Act was vintage Johnson-a measure pressed for two years and then finally manipulated under duress by a relentless president intent on snatching victory from the jaws of defeat. Johnson's achievement was one he could rightfully share with the nation. While the legislative victory may have been helped by Martin Luther King's assassination, it was Lyndon Johnson's political persistence in employing a rhetoric of transcendence that had finally challenged Americans to come to terms fully with and act justly in an arena that constituted one of the most sensitive and volatile domestic policy issues of the decade-fair housing. While LBJ's legislation would receive criticism for lacking teeth and kowtowing to white fears, to his credit, President Johnson never relented and never looked back-save to savor a hard-won rhetorical and political battle.

\section{NOTES}

1. Lyndon Baines Johnson, "Special Message to Congress on Urban Problems: 'The Crisis of the Cities," Public Papers of the Presidents of the United States: Lyndon B. Johnson, 1968-1969, Book I, Washington, D.C.: U.S. Government Printing Office, 263. Hereafter cited as Public Papers, 1968-1969, I.

2. David Zarefsky, “The Great Society as a Rhetorical Proposition,” Quarterly Journal of Speech 65 (1979): 364-78.

3. Both quotations may be found in Donald M. Fraser to George Reedy, September 1, 1965, HU 2-2 General File, 11-22-63-6-30-65, box 48, LBJ Library.

4. William L. O'Neill, Coming Apart: An Informal History of America in the 1960s (New York: Quadrangle Books, 1971), 165.

5. Nicholas Katzenbach, "Remarks by Attorney General Nicholas deB. Katzenbach, St. Louis Conference on Equal Opportunity in Housing, Chase Park Plaza Hotel, St. Louis, Missouri. Tuesday, June 15, 1965, 7:00 P.M. CDT," HU 2-2 General File, 11-22-63-6-30-65, box 48, LBJ Library.

6. As an undated draft of a speech endorsing a federal rent supplement program contained in the proposed Housing Act of 1965 noted, "The latest census reveals 8 million American families living in slum housing. One-third of all families in some cities occupy slum or sub-standard housing. Four million rural families are similarly penalized. We are ten years behind our public housing goals, and 
sliding still." "Rent Supplements Speech," undated, Housing (3), Aides: Harry McPherson, box 23, LBJ Library.

7. Kennedy's executive order was a result of an overblown campaign promise that he could remove housing discrimination "with the stroke of a pen." When he continued to postpone issuing his promised order on this controversial issue, people actually began to send him pens. When the order was issued, it was limited to housing built or bought with federal aid or financed by private mortgages that had been guaranteed or insured by federal agencies (for example, FHA [Federal Housing Administration] or VA [Veterans Administration] loans). The biggest flaw in the order was that independent banks and savings and loans who had federally insured deposits through the Federal Deposit Insurance Corporation (FDIC) were exempted. This flaw meant that much of the nation's housing stock was left uncovered.

8. A. Philip Randolph to LBJ, May 5, 1965, HU 2-2 General File, 11-22-63-6-30-65, box 48, LBJ Library.

9. Charles Abrams and Edward Rutledge to LBJ, November 16, 1964, HU 2-2 General File, 11-2263-6-30-65, box 48, LBJ Library; and see, for example, National Committee Against Discrimination in Housing, "Statement and Recommendations on Executive Order No. 11063, Prohibiting Discrimination in Federally-Assisted Housing," HU 2-2 General File, 11-22-63-6-30-65, box 48, LBJ Library.

10. Pressure came from a variety of other sources, including Whitney Young of the National Urban League and Roy Wilkins of the NAACP. See, for example, Whitney Young to LBJ, April 21, 1965, HU General File, 11-22-63-6-30-65, box 48, LBJ Library; Wilkins to LBJ, May 5, 1965, HU General File, 11-22-63-6-30-65, box 48, LBJ Library; Kenneth C. Jones and Frederick B. Routh to LBJ, June 11, 1965; W.T. McCullough to LBJ, June 22, 1965, HU 2-2 General File, 11-22-63-6-30-65, box 48, LBJ Library.

11. "Nondiscrimination in Housing — Title VIII of the Civil Rights Act of 1968," 1966-Preparation of the Bill-Justice Department Material, folder 1, Legislative Background: Fair Housing Act of 1968, box 1, LBJ Library. For further discussion, see Harry McPherson Oral History. Interviewed by T. H. Baker. tape 8, 4, LBJ Library.

12. Johnson, “The President's Message to Congress, April 28, 1966," Weekly Compilation of Presidential Documents 2, no. 17 (May 2, 1966): 581-90; quotation, 582. Hereafter cited as WCPD, 1966.

13. WCPD, 1966, 582-83.

14. WCPD, 1966, 584.

15. WCPD, 1966, 587.

16. WCPD, 1966, 588.

17. WCPD, 1966, 588.

18. WCPD, 1966, 589.

19. Robert Dallek, Flawed Giant: Lyndon Johnson and His Times, 1961-1973 (New York: Oxford University Press, 1998), 335.

20. As it turned out, administration fears were justified. The Democrats lost 3 Senate seats, 47 House seats, and 8 gubernatorial races. Dallek, Flawed Giant, 338-39.

21. Memo, Clifford Alexander to Harry McPherson, December 17, 1966, HU 2-2, Executive File, box 48, LBJ Library.

22. Memo, Clark Clifford to LBJ, July 27, 1966, 1966-Legislative Relations, Legislative Background: Fair Housing Act of 1968, box 4, LBJ Library. 
23. Memo, Katzenbach to LBJ, July 28, 1966, 1966-Legislative Relations, Legislative Background: Fair Housing Act of 1968, box 4, LBJ Library.

24. Memo, Alexander to LBJ, August 24, 1966, Cabinet Meeting, 8-25-66 [1 of 4], Cabinet Papers, box 7, LBJ Library.

25. Johnson, "Equal Justice.' The President's Message to the Congress Setting Forth a Seven-Point Civil Rights Program, February 15, 1967," Weekly Compilation of Presidential Documents 3, no. 7 (February 20, 1967): 248-60; quotation, 255. Hereafter cited as WCPD, 1967.

26. WCPD, 1967, 260.

27. “The President: Something Borrowed," Newsweek, February 27, 1967, 27-28.

28. In January 1967 we had 500,000 troops in Vietnam. As casualties continued to mount, antiwar protest escalated. By January 30, 1968, the Vietcong and their allies launched the "Tet" offensive, which was a shocking wake-up call for most Americans, highlighting the ferocity and deep entrenchment of an implacable enemy. As Dan T. Carter notes, "The war in Vietnam and the expansion of the anti-war movement, coupled with summer after summer of civil disorder, left the incumbent administration discredited and the nation deeply divided." See Dan T. Carter, The Politics of Rage: George Wallace, the Origins of the New Conservatism, and the Transformation of American Politics, 2d ed. (Baton Rouge: Louisiana State University Press, 2000), 325-26.

29. George N. Dionisopoulos, Victoria J. Gallagher, Steven R. Goldzwig, and David Zarefsky, "Martin Luther King, Jr., the American Dream and Vietnam: A Collision of Rhetorical Trajectories," Western Journal of Communication 56 (1992): 91-107.

30. "Racial Violence Potential in the United States This Summer," FBI Confidential Report, May 23, 1967, CF-HU2, box 56, LBJ Library.

31. As Dan T. Carter observes, "The race riots of 1966 and 1967 and the increasing federal pressure to integrate northern schools and housing made it apparent that capital could be made among discontented white Democrats in the North as well as in the South." Dan T. Carter, From George Wallace to Newt Gingrich: Race in the Conservative Counterrevolution, 1963-1994 (Baton Rouge: Louisiana State University Press, 1996), 30-31. The extant polls supported his claim. See, for example, Hazel Erskine, "The Polls: Demonstrations and Race Riots," Public Opinion Quarterly 8 (1967-68): 655-67; Hazel Erskine, “The Polls: Negro Housing," Public Opinion Quarterly (1967): 4 82-98.

32. Johnson was to experience violent urban civil unrest for four consecutive years leading up to 1968. Chief among these disturbances were outbreaks of violence in Harlem and Philadelphia in 1964, Watts in 1965, Cleveland in 1966, and Newark and Detroit in 1967.

33. "Civil Rights: 'We Haven't Really Improved-We May Have Slipped," U.S. News \& World Report, May 1, 1967, 50.

34. In July 1967, in Newark, New Jersey, rumors of police brutality visited upon a black cab driver touched off six days of rioting resulting in the loss of 26 lives, 1,500 injuries, and a rash of fires that gutted the city. As Dallek suggests, "The Newark riots threw Johnson into a mood of near despair." Dallek, Flawed Giant, 412. Newark's embers were still smoldering when Detroit flared. Joseph Califano later reflected that the riots in Detroit in 1967 represented "the nation's worst disturbance since federal troops had been required . . . in 1943." Joseph Califano, Jr., The Triumph and the Tragedy of Lyndon Johnson: The White House Years (New York: Simon and Schuster, 1991), 213. Detroit yielded some sorry statistics as well: 40 people had died, 2,000 were injured, 5,000 were arrested, and 5,000 were left homeless. Califano, The Triumph and the Tragedy, 220. A July 1967 poll registered a paltry 38 percent approval rating for the president. Barbara Hinckley, The Symbolic Presidency: How Presidents Portray Themselves (New York: Routledge, 1990), 32. 
35. P. H. Zernicke, Pitching the Presidency: How Presidents Depict the Office (Westport, Conn.: Praeger, 1994), 63.

36. Zernicke, Pitching the Presidency, 63.

37. Dallek, Flawed Giant, 412.

38. Memo, Fred Panzer to LBJ, August 15, 1967, HU 2-2 Executive File, 5-1-67-7-31-68, box 48, LBJ Library. The riots also had led to altered perceptions of Johnson's ongoing poverty programs. Approximately three months later, on November 17, 1967, Panzer notified the president that a new Harris poll scheduled for release November 20 indicated that a majority of Americans still favored "'a massive governmental program"” to address "ghetto discontent." He observed pointedly, however, that the majority that favored tearing the ghettos down, giving jobs to inner-city unemployed, exterminating rats in the slums, and establishing summer youth camps, was down 8 to 12 points since August 1967. This poll pointed out the problem Lyndon Johnson had in calling for new programs to address the rot at the urban core while the urban core was on fire. See Memo, Panzer to LBJ, November 17, 1967, Civil Rights/Negroes, folder 1, Aides: Marvin Watson, box 18, LBJ Library.

39. Dallek, Flawed Giant, 417.

40. Dallek, Flawed Giant, 411.

41. Memo, Panzer to Joseph Califano, February 15, 1967, 1967-Legislative Relations, Legislative Background: Fair Housing Act of 1968, box 4, LBJ Library.

42. While it is impossible in this context to go over every change and every provision of the comprehensive omnibus Civil Rights Acts of 1966 and 1967, it is enough here to suggest that the 1967 initiatives were similar to those proposed in 1966. See "Nondiscrimination in Housing_-Title VIII of the Civil Rights Act of 1968," 1966 — Preparation of the Bill—Justice Department Material, folder 1, Legislative Background: Fair Housing Act of 1968, box 1, LBJ Library.

43. Johnson, "Special Message to Congress on Civil Rights, January 24, 1968," Public Papers, 1968-1969, I, 55-64; quotation, 61-62.

44. Public Papers, 1968-1969, I, 61.

45. Public Papers, 1968-1969, I, 61-62.

46. Public Papers, 1968-1969, I, 62; and see WHCF, Aides File, Panzer, Panzer-Civil Rights, 1967-1968, "Civil Rights Bill Voted by the House," newspaper article, New York Times, April 11, 1968, box 331, LBJ Library. Johnson's new housing provision was similar to the one introduced in 1967. Essentially the housing statute was designed to combat discrimination in housing in three stages: (1) it barred discrimination in the sale or rental of federally owned housing and multi-unit dwellings whose mortgages were insured or underwritten by the FHA or the VA; (2) it prohibited discrimination in all multifamily units such as apartments and real estate developments (but excluded owner-occupied units of four or fewer units, that is, what euphemistically was labeled "Mrs. Murphy's" boarding house-type dwellings; and (3) it outlawed discrimination in the sale or rental of single-family homes handled through a real estate agency. It was further stipulated that individual homeowners who decided not to sell their home through a real estate broker or agent could discriminate, but they were not allowed to post discriminatory signs or use discriminatory advertisements.

47. Public Papers, 1968-1969, I, 62.

48. See WHCF Aides File, Panzer, Civil Rights 1967-1968, newspaper article, "Civil Rights Measure Main Points Outlined," Washington Evening Star, April 11, 1968, box 331, LBJ Library.

49. Telegram, Rutledge and Jack E. Wood to LBJ, Civil Rights Message Response, Aides: Panzer, box 386, LBJ Library. 
50. Democratic National Committee News Release, January 25, 1968, "President Johnson Praised for Civil Rights Message," Civil Rights/Negroes, folder 1, Aides: Marvin Watson, box 18, LBJ Library.

51. Memo, Mike Manatos to LBJ, February 13, 1968, 1968-Legislative Relations, Legislative Background: Fair Housing Act of 1968, box 4, LBJ Library.

52. See, for example, memo, Califano to LBJ, February 17, 1968, 1968-Legislative Relations, Legislative Background Fair Housing Act of 1968, box 4, LBJ Library; "Letter to Senator Hart Expressing His [Johnson's] Views on Pending Civil Rights Legislation," February 19, 1968, Public Papers, 1968-1969, I, 243.

53. Memo, Ramsey Clark to LBJ, February 20, 1968, 1968-Legislative Relations, Legislative Background: Fair Housing Act of 1968, box 4, LBJ Library.

54. "Opening the Doors," Time, April 19, 1968, 20-21.

55. LBJ to John McCormack, March 11, 1968, 1968-Legislative Relations, Legislative Background: Fair Housing Act of 1968, box 4; LBJ to McCormack, March 11, 1968, Civil Rights, Personal Papers of Barefoot Sanders, Jr., box 17, LBJ Library.

56. LBJ to Clarence Mitchell, March 11, 1968, HU 2-2 Executive File, 5-1-67-7-31-68, box 48, LBJ Library.

57. On March 13, 1968, some segments of the administration were leaning toward attempting to guide the bill to conference committee where it was felt the legislation might have a better chance of ultimate enactment. Another option was to call for a vote on a rule to concur. Even if the rule to concur were favorable, a general House motion to concur with the Senate on the bill had drawbacks such as placing House Republicans against those in the Senate, which would mitigate bipartisan support. In addition, while an agreement to send the bill to conference committee might have been acceptable to the Republicans, it also posed the danger of increased delay, which would anger civil rights groups who opposed the conference committee method and, it was surmised, did not fully understand the perilous parliamentary predicament the vote on a rule to concur presented. See memo, Harold "Barefoot" Sanders to LBJ, March 13, 1968, 2:45 P.M., 1968-Legislative Relations, Legislative Background: Fair Housing Act of 1968, box 4, LBJ Library.

58. LBJ's announcement included this terse statement: "I shall not seek, and I will not accept, the nomination of my party for another term as your President." Johnson, "The President's Address to the Nation Announcing Steps to Limit the War in Vietnam and Reporting his Decision Not to Seek Reelection, March 31, 1968," Public Papers of the Presidents, 1968-1969, I, 469-76; quotation, 476.

59. Johnson, "Statement by the President on the Assassination of Dr. Martin Luther King, Jr.," Public Papers, 1968-1969, I, 493.

60. Johnson, "Address to the Nation Upon Proclaiming a Day of Mourning Following the Death of Dr. King," Public Papers, 1968-1969, I, 493-95; quotations, 493-94. The implications of the series of messages LBJ crafted in response to the King assassination will be treated later in this essay.

61. According to Steven F. Lawson, "a week of violence plagued more than 100 communities, leaving 46 people dead, over 3,000 injured, and 27,000 incarcerated and costing in excess of $\$ 45$ million in property damages; it required 21,000 federal troops and 34,000 National Guardsmen to restore peace." See Steven F. Lawson, "Mixing Moderation with Militancy: Lyndon Johnson and AfricanAmerican Leadership," in The Johnson Years, vol. 3: LBJ at Home and Abroad, ed. Robert A. Divine (Lawrence: University Press of Kansas, 1994), 82-116; quotation, 102.

62. Memo, Ben Wattenberg to McPherson, April 5, 1968, Riots Speech, Aides: McPherson, box 44, LBJ Library. 
63. Memo, Wattenberg to McPherson, April 6, 1968, Riots Speech, Aides: McPherson, box 44, LBJ Library.

64. Memo, Panzer to LBJ, April 6, 1968, Riots Speech, Aides: McPherson, box 44, LBJ Library.

65. Memo, Alexander to LBJ, April 6, 1968, Riots Speech, Aides: McPherson, box 44, LBJ Library.

66. Memo, Fred Bohen to McPherson, April 8, 1968; memo, Albert H. Cantril to Bohen, April 8, 1968; Riots Speech, Aides: McPherson, box 44, LBJ Library.

67. Memo, Robert C. Weaver to McPherson, April 8, 1968, Riots Speech, Aides: McPherson, box 44, LBJ Library.

68. Johnson, "Address to the Nation Upon Proclaiming a Day of Mourning," 493-94; quotation, 494.

69. Johnson, "Letter to the Speaker of the House Urging Enactment of the Fair Housing Bill, April 5, 1968," Public Papers, 1968-1969, I, 496-97; quotation, 497.

70. Kenneth Burke argues that transcendent rhetoric serves as a "bridge whereby one realm is transcended by being viewed in terms of a realm 'beyond it."' Kenneth Burke, Language as Symbolic Action: Essays on Life, Literature, and Method (Berkeley: University of California Press, 1966), 187. According to Stewart, Smith, and Denton, "In a rhetoric of transcendence, persuaders argue that a person, group, goal, thing, right action, or proposal surpasses, is superior to, or was prior to its opposite." Moreover, the rhetoric of transcendence allows the rhetor to identify symbolically "with what is large, good, important, and of the highest order." Charles J. Stewart, Craig Allen Smith, and Robert E. Denton, Jr., Persuasion and Social Movements, 4th ed. (Prospect Heights, Ill.: Waveland Press, 2001), 274 and 277.

71. Kenneth Burke, Attitudes Toward History, 3d ed. (Berkeley: University of California Press, 1984), 337.

72. Kenneth Burke, A Grammar of Motives (Berkeley: University of California Press, 1969), 421.

73. Kenneth Burke, Attitudes Toward History, 82.

74. Kenneth Burke, Attitudes Toward History, 84.

75. Kenneth Burke, Attitudes Toward History, 88.

76. Kenneth Burke, The Rhetoric of Religion: Studies in Logology (Berkeley: University of California, 1961/1970), 58.

77. "Opening the Doors," 20-21.

78. "Telegram to the Acting Governor of Illinois [Samuel H. Shapiro] in Response to His Request for Federal Troops in Chicago, April 6, 1968," Public Papers, 1968-1969, I, 497; "Telegram to the Governor of Maryland [Spiro T. Agnew] in Response to His Request for Federal Troops in Baltimore, April 7, 1968," Public Papers, 1968-1969, I, 498.

79. Johnson, "The President's News Conference of April 10, 1968," Public Papers, 1968-1969, I, 504.

80. Johnson, "Broadcast Statement by the President Following the Passage of the Civil Rights Act, April 10, 1968," Public Papers, 1968-1969, I, 507. The open housing portion of the legislation that became part of the 1968 Civil Rights Act was enacted as Title VIII.

81. Interview with author, March 3, 1996, LBJ Library. Middleton's claim is corroborated by Harry McPherson in his oral history. As I have argued, however, the best evidence for this assertion can be found in Lyndon Johnson's own discourse. Barefoot Sanders maintained that King's assassination was not pivotal in passing the legislation because, in his words, "the yeas and the nays canceled each other out." Nevertheless, sympathy on Capitol Hill had been especially enervated by the rioting in Washington, D.C., immediately after King's death. As outlined earlier, the president's bill had already been approved by the Senate and was being considered by the House when King fell in 
Memphis. See Steven F. Lawson, “Civil Rights," in Exploring the Johnson Years, ed. Richard A. Divine (Austin: University of Texas Press, 1981), 105-6.

82. Memo, Sanders to LBJ, April 10, 1968, 1968-Legislative Relations, Legislative Background: Fair Housing Act of 1968, box 4, LBJ Library.

83. Johnson, “Remarks Upon Signing the Civil Rights Act, April 11, 1968," Public Papers, 1968-1969, I, 509-10. H.R. 2416 became Public Law 90-284 (82 Stat. 73).

84. Wayne Fields, Union of Words: A History of Presidential Eloquence (New York: Free Press, 1996), 262.

85. George C. Edwards, III, The Public Presidency (New York: St. Martin's Press, 1983); George C. Edwards, III, "Director or Facilitator? Presidential Policy Control of Congress," in The Managerial Presidency, ed. James P. Pfiffner (Pacific Grove, Calif.: Brooks/Cole, 1991), 214-24.

86. Doris Kearns, Lyndon Johnson and the American Dream (New York: Harper and Row, 1976), 308.

87. Vaughn D. Bornet, The Presidency of Lyndon B. Johnson (Lawrence: University Press of Kansas, 1983), 95-96.

88. Harvard Sitkoff, The Struggle for Black Equality, 1954-1992, rev. ed. (New York: Hill and Wang, 1993), 211.

89. Johnson, “Address Before a Joint Session of Congress," November 27, 1963, Public Papers of the Presidents of the United States: Lyndon B. Johnson, 1963-1964, Book I (Washington, D.C.: U.S. Government Printing Office, 1965), 8-9.

90. Johnson, "Statement by the President on the Situation in Selma, Alabama," March 9, 1965, Public Papers of the Presidents of the United States: Lyndon B. Johnson, 1965, Book I (Washington, D.C.: U.S. Government Printing Office, 1966), 272. Hereafter cited as Public Papers, 1965.

91. Johnson, “The President's News Conference of March 13, 1965,” Public Papers, 1965, I, 274-75.

92. Johnson, "Special Message to Congress: The American Promise," March 15, 1965, Public Papers, 1965, I, 281.

93. Johnson, "Remarks in the Capitol Rotunda at the Signing of the Voting Rights Act," August 6, 1965, Public Papers 1965, II, 841.

94. Johnson, “Address to the Nation Following the Attack on Senator Kennedy," June 5, 1968, Public Papers, 1968-1969, I, 692.

95. Johnson, "Letter to the President of the Senate and the Speaker of the House Urging Passage of an Effective Gun Control Law," June 6, 1968, Public Papers, 1968-1969, I, 694-95.

96. Sitkoff, The Struggle for Black Equality, 211.

97. James C. Harvey, Black Civil Rights During the Johnson Administration (Jackson: University and College Press of Mississippi, 1973), 98-99.

98. Harvey, Black Civil Rights, 100.

99. Lawson, "Civil Rights," 103.

100. Fields, Union of Words, 266. 